\title{
An underestimated comorbidity of COPD: Thyroid dysfunction
}

\author{
Evrim Eylem AKPINAR ${ }^{1}$
}

${ }^{1}$ Clinic of Chest Diseases, Dr. Ridvan Ege Hospital, Ufuk University, Ankara, Turkey

${ }^{1}$ Ufuk Üniversitesi Dr. Rıdvan Ege Hastanesi, Göğüs Hastalıkları Kliniği, Ankara, Türkiye
Cite this article as: Akpınar EE. An underestimated comorbidity of COPD: Thyroid dysfunction. Tuberk Toraks 2019;67(2):131-5.

\section{Yazışma Adresi (Address for Correspondence)}

\section{Dr. Evrim Eylem AKPINAR}

Ufuk Üniversitesi Dr. Rıdvan Ege Hastanesi, Göğüs Hastalıkları Kliniği, ANKARA - TÜRKIYE e-mail: drevrimeylem@gmail.com

CCopyright 2019 by Tuberculosis and Thorax. Available on-line at www.tuberktoraks.org.com

\section{SUMMARY}

An underestimated comorbidity of COPD: Thyroid dysfunction

Chronic obstructive pulmonary disease (COPD) has many systemic effects influencing morbidity and mortality of the disease. Thyroid diseases which are more common in COPD patients than who do not have COPD are underestimated despite important clinical consequences. Similar to general population, thyroid dysfunctions are more common in females than males among COPD patients. Both hypothyroidism and hyperthyroidism may be associated to COPD. As well as systemic inflammation hypoxia, age, glucocorticoid use and smoking are some of the effective factors on developing thyroid dysfunction in COPD patients. In this article thyroid dysfunctions that are underrecognized comorbidities of COPD patients, their mechanisms of action and clinical outcomes were reviewed.

Key words: Chronic obstructive pulmonary disease; comorbidity; thyroid gland

\section{ÖZET}

\section{KOAH'ta göz ardı edilen bir komorbidite: Tiroid disfonksiyonu}

Kronik obstrüktif akciğer hastalığı $(K O A H)^{\prime}$ 'nın morbidite ve mortalitesini etkileyen birçok sistemik etkisi vardır. KOAH'lı hastalarda KOAH olmayanlara göre daha sık görülen tiroid hastalıkları önemli klinik sonuçlarına rağmen yeterince önemsenmemektedir. Genel popülasyona benzer bir şekilde tiroid disfonksiyonları kadın KOAH'lılarda erkeklerden daha sık görülmektedir. Hem hipotiroidizm hem de hipertiroidizm KOAH'a eşlik edebilmektedir. KOAH'ı hastalarda sistemik inflamasyonun yanı sıra hipoksi, yaş, glukokortikoid kullanımı ve sigara içilmesi tiroid disfonksiyonu gelişiminde etkili olan bazı faktörlerdir. Bu derlemede KOAH'lı hastalarda az bilinen bir komorbidite olan tiroid disfonksiyonları, gelişim mekanizmaları ve klinik sonuçları gözden geçirilmiştir.

Anahtar kelimeler: Kronik obstrüktif akciğer hastalı̆̆ı; komorbidite; tiroid bezi 


\section{INTRODUCTION}

Chronic obstructive pulmonary disease (COPD) is a leading cause of morbidity and mortality worldwide. The disease courses with chronic airway inflammation. The inflammation not only affect the airways but also has systemic effects that are main causes of comorbidities (1). Some comorbidities such as coronay artery disease, metabolic syndrome are well-recognised in COPD patients. But, thyroid diseases which are more common in COPD patients than who do not have COPD are underestimated despite important clinical consequences (2). Similar to general population, thyroid dysfunctions are more common in females than males among COPD patients. In a large COPD cohort from Spain, prevelance of thyroid diseases was reported as $14.2 \%$ and it was found higher in females than males (24.6 vs $10.9 \%$ ) (3).

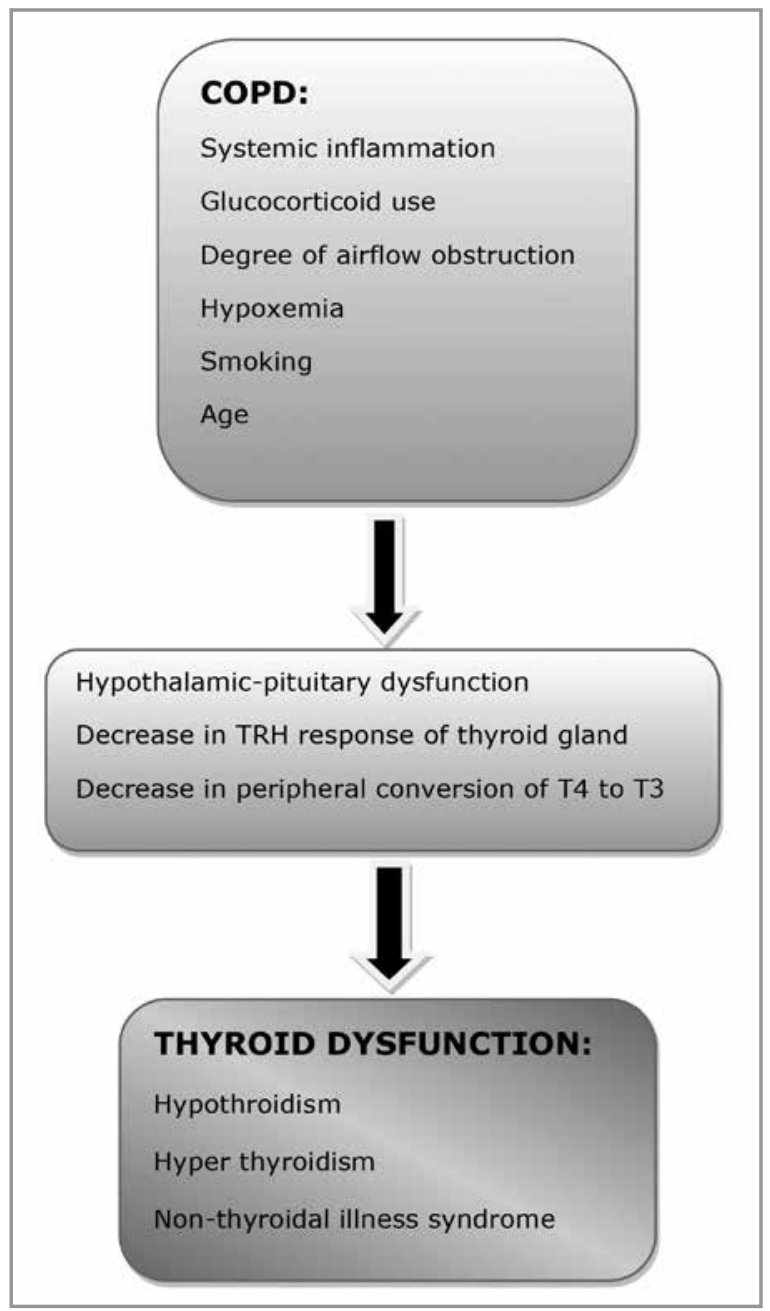

Figure 1. The relationship between chronic obstructive pulmonary disease and thyroid gland dysfunction.
Thyroid hormones have an important role in regulation of metabolism. They may change the respiratory drive as a result of their effects on metabolic rate and transcription of some genes related to myofibres (4). Systemic inflammation may express the link between COPD and tyhroid diseases. Supporting this postulate, Karadag et al. found a positive correlation between IL-6 which is a systemic inflammation marker and total triiodotironine (TT3) and TT3/TT4 (total tyhroxine) in patients with stable COPD (5). Smoking itself increase systemic inflammation independently from associating COPD and may affect throid functions. Both of the hypothyroidism and hyperthyroidism may associate with COPD (4). The aim of the article is to review thyroid dysfunctions in patients with COPD and to emphasize clinical consequences of these comorbidities which are usually underestimated. The relationship between COPD and thyroid gland dysfunction was summarized on Figure 1.

\section{Hypothyroidism and COPD}

Hypothyroidism is more frequent than hyperthroidism among COPD patients. Patients with COPD can present with increased systemic levels of inflammatory cytokines such as IL-6, IL-1 and TNF-a that can inhibit the synthesis or secretion of thyroid stimulating hormone (TSH), T3 and thyroid hormone-binding proteins, and can decrease the conversion of $\mathrm{T} 4$ to $\mathrm{T} 3$ (6). In addition to systemic inflammation severity of airflow obstruction, hypoxemia and corticosteroid use in COPD patients are predisposing factors in development of hypothyroidism. Moreover, aging also was suggested as a determinant factor on hypothalamic-pituitary dysfunction in elderly patients with COPD (7). Glucocorticoids which are frequently used in COPD treatment may cause decrease in serum TSH and in conversion of T4 to T3. They also may lead to redistribution of thyroid hormones in body fluids (6).

Previous studies showed that hypothyroidism was more common than hyperthyroidism in COPD patients and its frequency showed positive correlation with the stage of COPD $(8,9)$. Hypothyroidism may cause respiratory muscle dysfunction in patients with or without COPD. The decrease in neuromuscular transmission and expression of some proteins related to myofibers are main causes of the dysfunction of respiratory muscles. Phrenic nerve neuropathy also may contribute to weakness of respiratory muscles (6). Ulaslı et al. found that maximum expiratory pressure (MEP) levels were significantly lower in COPD patients 
with hypothyroidism than in those without it (10). Moreover, Terzano et al. showed that COPD patients with hypothyrodism had lower $\mathrm{PaO}_{2}$ and a tendency to increase in $\mathrm{PCO}_{2}$ levels. They also found that levels of maximum inspiratory pressure (MIP) and MEP were lower in this group of COPD patients $(10,11)$. Dimopoulou et al. found a positive correlation between TT3/TT4 and $\mathrm{PaO}_{2}$ in COPD patients who had $\mathrm{FEV}_{1}<50 \%$ (12). Alveolar hypoventilation secondary to respiratory muscle dysfunction and decreased ventilatory drive may enhance hypoxemia and hypercapnia in COPD patients (6).

The exacerbation frequency was found to be higher in COPD patients associated with hypothroidism than those did not $(8,10)$. The frequency of COPD exacerbation was positively correlated with TSH levels and TSH value was found as a significant determinant of exacerbation frequency (10). Furthermore, Bacakoglu et al. demonstrated that low fT3 and fT4 levels increase the rates of invasive mechanical ventilation and mortality in patients with respiratory failure $(12,13)$. Although COPD patients with hypothyroidism have exercise intolerance and decreased maximal oxygen uptake, the study of Ulaslı et al. concluded that hypothyroidism was not a factor affecting quality of life in COPD patients $(5,10)$. Further studies are needed to determine effects of hypothyroidism on COPD exacerbation and also to clarify its effects on outcomes of respiratory failure and quality of life in COPD patients.

Obstructive sleep disorders are commonly seen in hypothyroid patients with or without COPD. Obesity, mucoprotein deposition and myopathy and, decreased ventilatory drive are possible causes of sleep disorders in hypothyroid patients (4).

The treatment of hypothroidism associated with COPD does not differ from the treatment of patients without it (6). Although some negative effects of hypothyroidism may be reversed with treatment, the effect of treatment on lung functions and prognosis is not well known and should be clarified with future studies.

Clinical consequences and their mechanisms in COPD patients with hypothyroidism were shown on Table 1.

\section{Hyperthyroidism and COPD}

Hyperthyroidism is less frequently seen than hypothroidism in COPD patients. Muscle weakness due to loss of muscle mass and strength as a result of increased catabolism can be seen in COPD patients with hypertyroidism. COPD patients who have cachexia should be investigated whether they have concomitant hyperthyroidism. Muscle wasting that is already present in COPD patients may be aggrevated by hyperthyroidism (4). Siafakas et al. reported that inspiratory and expiratory muscle weakness (decrease in $\mathrm{FEV}_{1}, \mathrm{FVC}, \mathrm{VC}, \mathrm{MEP}$ and MIP) was proportional to the level of hyperthyroidism and reversible with treatment in thyrotoxic patients (14).

The increase in TT3/TT4 and fT3 in COPD patients were previously reported $(10,15)$. El-Yazed et al. demonstrated that the increase in $\mathrm{fT} 3$ showed negative correlation with $\mathrm{PaO}_{2}$ and positive correlation with

Table 1. Clinical consequences and their mechanisms in chronic obstructive pulmonary disease patients with hypothyroidism

\begin{tabular}{|lc|}
\hline Clinical consequence & Mechanism \\
\hline Decrease in MEP and MIP & $\begin{array}{c}\text { Respiratory muscle dysfunction: } \\
\text { Decrease in neuromuscular transmission } \\
\text { Decrease in myofiber protein expression } \\
\text { Phrenic nerve neuropathy } \\
\text { Alveolar hypoventilation }\end{array}$ \\
$\begin{array}{l}\text { Decrease in ventilatory drive } \\
\text { Respiratory muscle weakness } \\
\text { Pbstructive sleep disorders }\end{array}$ & $\begin{array}{c}\text { Obesity } \\
\text { Increase in exacerbation }\end{array}$ \\
& $\begin{array}{c}\text { Mucoprotein deposition } \\
\text { Myopathy }\end{array}$ \\
& $\begin{array}{c}\text { Decrease in ventilatory drive } \\
\text { Respiratory muscle dysfunction } \\
\text { Decrease in ventilatory drive }\end{array}$ \\
\hline MEP: Maximum expiratory pressure, MIP: Maximum inspiratory pressure. & Susceptibility to respiratory infections \\
\hline
\end{tabular}


$\mathrm{PaCO}_{2}$ and also proportional to the severity of COPD (15). The excess T3 level causes proteolysis which can be augmented by glucocorticoid treatment in respiratory muscles including diaphragma. In addition to increase in T3 levels, loss of TSH response to thyroid releasing hormone (TRH) was another disturbance that was shown in elderly severe COPD patients (7).

The risk of respiratory failure is increased in patients with hyperthyroidism as a result of respiratory muscle weakness, decreased lung compliance and increased sensitivity of peripheral and central chemoreceptor sensitivity (6). Treatment of COPD patients with hyperthyroidism is same with hyperthyroid patients without COPD.

\section{Non-Thyroidal Illness Syndrome in COPD}

Non-thyroidal illness syndrome (NTIS) is caharactarized by a decrease in peripheral conversion of $\mathrm{T} 4$ to T3 because of a systemic disease (16). It is the most frequent type of thyroid function impairment among COPD patients. The estimated prevelance of NTIS is $14-20 \%$ in patients with stable COPD and $70 \%$ in exacerbation period. The levels of T3 which is biologically active hormone decreased, T4 levels are normal or decreased in NTIS and they usually have a normal level of TSH (6).

Karadag et al. investigated thyroid hormone levels in COPD patients both in stable phase and exacerbation period and in control group. They found that fT3 levels and TT3/TT4 ratio were lower in the COPD group than in controls. Additionally, they demonstrated that alterations in thyroid hormone levels were more prominent in exacerbation period and they turned to normal levels subsequent to recovery of exacerbation. They also reported that stable COPD patients had significant changes in thyroid hormones, which were correlated with severity of disease and hypoxemia (5). The authors warned about that the assesment of thyroid function during exacerbation period may be misleading and thyroid function abnormalities in stable phase related to non-thyroid illness may mimic true thyroid disease (5).

NTIS may causes worse outcomes in clinical course of COPD patients. Yasar et al. examined the relationship between NTIS and prolonged weaning in COPD patients admitted to the ICU. They reported that NTIS had predictive role for prolonged weaning in COPD patients who undergone invasive mechanical ventilation (17).
Mancini et al. investigated the relationship between thyroid hormones and antioxidant systems, the lipophilic Coenzyme Q10 and total antioxidant capacity in COPD patients. They found lower antioxidant capacity in COPD patients with normal fT3 levels, compared to healthy control group and further significant reduction in COPD patients with low level of fT3. They suggested that oxidative stress increases in COPD patients with low level of fT3 and these patients may benefit from thyroid replacement therapy (18). It is not yet obvious whether supplemental therapy is usefull or not in all COPD patients with NTIS. Future studies are necessary to clarify effects of hormonal therapy in these patients.

\section{CONCLUSION}

Despite important clinical consequences that may negatively affect course and prognosis of the disease, tyhroid dysfunctions are frequently underrecognized comorbidities of COPD. Hypothyroidism is more prevelant than hypertyhroidism and NTIS is the most frequently seen thyroid dysfunction in COPD patients. Thyroid dysfunctions may cause worse clinical outcomes in COPD patients such as increase in exacerbation frequency and prolonged intubation. The evaluation of COPD patients for thyroid dysfunctions may be useful because hormone replacement therapy can reverse most of the negative effects of this comorbidity both in hypothyroid and hyperthyroid patients. But, its effect is not clear in COPD patients with NTIS. Future studies are needed to determine which COPD patients should be evaluated for thyroid dysfunctions and which NTIS patients will benefit from supplemental therapy. Population-based studies are necessary to find out exact prevelance of thyroid dysfunction in COPD patients.

\section{CONFLICT of INTEREST}

The authors reported no conflict of interest related to this articles.

\section{AUTHORSHIP CONTRIBUTIONS}

Concept/Design: EEA

Analysis/Interpretation: EEA

Data Acquisition: EEA

Writting: EEA

Critical Revision: EEA

Final Approval: EEA 


\section{REFERENCES}

1. Wouters EF, Creutzberg EC, Schols AM. Systemic effectsin COPD. Chest 2002;121(Suppl):S127-S30.

2. Miłkowska-Dymanowska J, Białas AJ, Laskowska P, Górski P, Piotrowski WJ. Underrecognized comorbidities of chronic obstructive pulmonary disease. International Journal of COPD 2015;10:1331-41.

3. García-Olmos L, Alberquilla A, Ayala V, García-Sagredo $P$, Morales L, Carmona M, et al. Comorbidity in patients with chronic obstructive pulmonary disease in family practice: a cross sectional study. BMC Fam Pract 2013;14:11.

4. Miłkowska-Dymanowska J, Białas AJ, Laskowska P, Górski P, Piotrowski WJ. Thyroid gland in chronic obstructive pulmonary disease. Adv Respir Med 2017;85:28-34.

5. Karadag $F$, Ozcan $H$, Karul AB, Yilmaz $M$, Cildag $O$. Correlates of non-thyroidal illness syndrome in chronic obstructive pulmonary disease. Respir Med 2007;101:1439-46.

6. Laghi F, Adiguzel N, Tobin MJ. Endocrinological derangements in COPD. Eur Respir J 2009;34:975-96.

7. Gow SM, Seth J, Beckett GJ, Douglas G. Thyroid function and endocrine abnormalities in elderly patients with severe chronic obstructive lung disease. Thorax 1987;42:520-5.

8. Chaudhary SC, Ahmad T, Usman K, Sawlani KK, Gupta $K K$, Verma AK, et al. Prevalence of thyroid dysfunction in chronic obstructive pulmonary disease patients in a tertiary care center in North India. J Family Med Prim Care 2018;7:584-88.

9. Singh L, Jain A, Agrawal A, Tandon R, Kumar H. A study of prevalence of thyroid disorders in chronic obstructive pulmonary disease patients at a tertiary care center in U.P. Int J Contemp Med Res 2016;3:1239-42.
10. Ulasli SS, Bozbas SS, Zeynep Ozen ZE, Ozyurek BA, Ulubay G. Effect of thyroid function on COPD exacerbation frequency: a preliminary study. Multidisciplinary Respiratory Medicine 2013;8:64.

11. Terzano C, Romani S, Paone G, Conti V, Oriolo F. COPD and thyroid dysfunctions. Lung 2014;192:103-9.

12. Dimopoulou I, Ilias I, Mastorakos G, Mantzos E, Roussos C, Koutras DA. Effects of severity of chronic obstructive pulmonary disease on thyroid function. Metab Clin Exp 2001; 50:1397-401.

13. Bacakoğlu F, Başoğ/u OK, Gürgün A, Bayraktar F, Kıran B, Özhan MH. Can impairments of thyroid function test affect prognosis in patients with respiratory failure? Tuberk Toraks 2007;55:329-35.

14. Siafakas NM, Milona I, Salesiotou V, Filaditaki V, Tzanakis $N$, Bouros D. Respiratory muscle strength in hyperthyroidism before and after treatment. Am Rev Respir Dis 1992; 146:1025-9.

15. El-Yazed HA, El-Bassiony M, Eldaboosy S, Ali El Gendi AA, Hashim M. Assessment of thyroid functions in patients with chronic obstructive pulmonary disease. Egyptian Journal of Chest Diseases and Tuberculosis 2013;62:38791.

16. Gupta $M$, Vardey S, Joshi N, Dixit R. Evaluation of thyroid dysfunction in chronic obstructive pulmonary disease. Biomed Res 2013;24:110-3.

17. Yasar Z, Kirakli C, Cimen P, Ucar ZZ, Talay F, Tibet G. Is non-thyroidal illness syndrome a predictor for prolonged weaning in intubated chronic obstructive pulmonary disease patients? Int J Clin Exp Med 2015;8:10114-21.

18. Mancini A, Corbo GM, Gaballo A, Raimondo S, Di Segni $C$, Gigliotti $P$, et al. Relationship between plasma antioxidants and thyroid hormones in chronic obstructive pulmonary disease. Exp Clin Endocrinol Diabetes 2012;120:623-8. 